\title{
Shift work and vascular events: systematic review and meta-analysis
}

\author{
(C) $(1 \otimes$ OPEN ACCESS
}

\author{
Manav V Vyas graduate student ${ }^{1}$, Amit X Garg professor ${ }^{123}$, Arthur V lansavichus information \\ specialist $^{3}$, John Costella research and instructional librarian ${ }^{4}$, Allan Donner professor ${ }^{15}$, Lars $\mathrm{E}$ \\ Laugsand $P h D$ candidate ${ }^{6}$, Imre Janszky researcher ${ }^{67}$, Marko Mrkobrada assistant professor ${ }^{25}$, \\ Grace Parraga associate professor ${ }^{8}$, Daniel G Hackam associate professor ${ }^{125}$
}

\begin{abstract}
${ }^{1}$ Department of Epidemiology and Biostatistics, Western University, London, ON, Canada; ${ }^{2}$ Department of Medicine, Western University; ${ }^{3}$ Kidney Clinical Research Unit, Lawson Research Institute, London, ON, Canada; ${ }^{4}$ Research and Instructional Services, Allan and Betty Taylor Library, Western University; ${ }^{5}$ Clinical Trials Unit, Robarts Research Institute, Western University; ${ }^{6}$ Department of Public Health, Norwegian University of Science and Technology, Trondheim, Norway; ${ }^{7}$ Department of Public Health, Karolinska Institute, Stockholm, Sweden; ${ }^{8}$ Imaging Research Laboratories, Robarts Research Institute and Department of Medical Biophysics, Western University
\end{abstract}

\begin{abstract}
Objective To synthesise the association of shift work with major vascular events as reported in the literature.

Data sources Systematic searches of major bibliographic databases, contact with experts in the field, and review of reference lists of primary articles, review papers, and guidelines.

Study selection Observational studies that reported risk ratios for vascular morbidity, vascular mortality, or all cause mortality in relation to shift work were included; control groups could be non-shift ("day") workers or the general population.

Data extraction Study quality was assessed with the Downs and Black scale for observational studies. The three primary outcomes were myocardial infarction, ischaemic stroke, and any coronary event. Heterogeneity was measured with the $\mathrm{I}^{2}$ statistic and computed random effects models.

Results 34 studies in 2011935 people were identified. Shift work was associated with myocardial infarction (risk ratio 1.23 , 95\% confidence interval 1.15 to $\left.1.31 ; I^{2}=0\right)$ and ischaemic stroke $(1.05,1.01$ to 1.09 ; $\mathrm{I}^{2}=0$ ). Coronary events were also increased (risk ratio $1.24,1.10$ to 1.39 ), albeit with significant heterogeneity across studies $\left(I^{2}=85 \%\right)$. Pooled risk ratios were significant for both unadjusted analyses and analyses adjusted for risk factors. All shift work schedules with the exception of evening shifts were associated with a statistically higher risk of coronary events. Shift work was not associated with increased rates of mortality (whether vascular cause specific or overall). Presence or absence of adjustment for smoking and socioeconomic status was not a source of heterogeneity in the primary studies. 6598 myocardial infarctions, 17
\end{abstract}

359 coronary events, and 1854 ischaemic strokes occurred. On the basis of the Canadian prevalence of shift work of $32.8 \%$, the population attributable risks related to shift work were $7.0 \%$ for myocardial infarction, $7.3 \%$ for all coronary events, and $1.6 \%$ for ischaemic stroke.

Conclusions Shift work is associated with vascular events, which may have implications for public policy and occupational medicine.

\section{Introduction}

Although definitions vary slightly across sources, shift work can be defined as employment in any work schedule that is not a regular daytime schedule (that is, approximately 0900 to 1700). ${ }^{1}$ The full spectrum of shift work comprises regular evening or night schedules, rotating shifts, split shifts, on-call or casual shifts, 24 hour shifts, irregular schedules, and other non-day schedules. Shift work has long been known to disrupt circadian rhythm, sleep, and work-life balance; however, flexible work patterns remain a necessary component for a dynamic, diversified industrial economy. ${ }^{2}$ The association of shift work with vascular disease is controversial. Conflicting data on this association exist, perhaps in part owing to varying methods, populations, and definitions of shift work and vascular or coronary events. ${ }^{3}$ Furthermore, previous syntheses are now outdated, did not use validated tools for assessing studies, did not capture all available data, and did not apply quantitative techniques to compute summary risk estimates. ${ }^{3-5}$

Given these uncertainties, we comprehensively analysed the epidemiology of shift work and vascular events. We were as expansive as possible in our review and did not limit it by study 
design or type of event analysed. Rather, our goal was to examine reasons for differing estimates in the literature in secondary and sensitivity analyses.

\section{Methods}

We planned and reported this systematic review in accordance with the preferred reporting items for systematic reviews and meta-analyses (PRISMA). ${ }^{6}$

\section{Literature search and selection}

We sought observational studies that reported risk ratios (or raw data from which we could derive risk ratios) for the association of shift work with vascular events or mortality. Because of the diversity of endpoints reported, we pre-specified three primary vascular outcomes for this review: myocardial infarction, any coronary event, and ischaemic stroke. Secondary outcomes included heart failure, haemorrhagic stroke, total mortality, cardiovascular mortality, coronary mortality, cerebrovascular mortality, and all cardiovascular events. Outcomes were typically defined by primary study authors using country specific iterations of the international classification of diseases coding system (web extra table A). "Any coronary event" was typically defined as the composite of myocardial infarction, coronary mortality, and hospital admissions due to coronary artery disease (however, certain studies limited their definition to one specific subset of coronary events, such as myocardial infarction or coronary death alone). We imposed no limitation by regional origin, study design, or nature of the control group, which could consist of day workers or the general population.

We systematically searched the following electronic bibliographic databases from their inception until 1 January 2012: Medline including PreMedline, Embase, BIOSIS Previews, Cochrane CENTRAL, Conference Proceedings Citation Index-Science, Google Scholar, ProQuest Dissertation Abstracts, Scopus, and Science Citation Index Expanded. We used database specific subject terms and keywords to generate an initial list of articles for closer scrutiny (extra table B). Two health information specialists (AVI and JC) designed and implemented the search in consultation with the rest of the team. To identify additional studies, we contacted experts in the field, screened reference lists of primary articles and review papers, and did internet searches of occupational medicine and labour department websites. Two reviewers (MVV and DGH) screened citations and rated articles independently for inclusion; disagreements were resolved through consultation with a third reviewer (MM).

\section{Data extraction}

We extracted details on study design, setting, definition of shift workers and controls, data sources, accrual interval, outcomes, and follow-up (for cohort studies). We rated methodological quality by using the 27 item Downs and Black scale, which was developed for assessing the design and reporting of both randomised and observational studies. ${ }^{7}$ We adapted this scale by removing three items pertaining exclusively to randomised trials (specifically, "blinding of study subjects to the intervention," "randomization to intervention groups," and "concealed randomized intervention assignment").

We classified shift work schedules according to the original study methodological descriptions as evening, night, rotating, mixed, and irregular or unspecified (see extra table A for individual study level definitions). Two reviewers (MVV and
DGH) independently extracted all outcome data after redaction of study citation information; subsequently, we consulted study authors about missing or unclear information. We extracted both unadjusted and adjusted risk estimates (where available) together with their confidence intervals or tests of statistical significance.

\section{Statistical analysis}

We preferentially pooled multivariable adjusted risk estimates where such estimates were reported; however, if no adjusted analysis was available ( $\mathrm{n}=2$ studies), we included the unadjusted estimate. In sensitivity analyses, we separately reported unadjusted and adjusted risk estimates for studies that reported both levels of adjustment. We calculated pooled risk ratios by synthesising across the shift schedules used in individual studies; we used generic inverse variance random effects models with $95 \%$ confidence intervals. We used the $\mathrm{I}^{2}$ statistic to measure heterogeneity; values of $0 \%$ to $30 \%$ represented minimal heterogeneity, $31 \%$ to $50 \%$ moderate heterogeneity, and greater than $50 \%$ substantial heterogeneity. ${ }^{8}$ We assessed our results by using the grading of recommendations assessment, development and evaluation (GRADE) framework. ${ }^{9}$

Because one of the primary outcomes (coronary events) indicated substantial heterogeneity, we used univariate random effects meta-regression to explore potential sources of inconsistency in this outcome. We tested the effects of characteristics of samples, rates of events, region of study, design of study, methodological quality, and whether reported associative measures were adjusted for smoking and socioeconomic status (noted in the occupational literature as important potential confounders for the relation of shift work with coronary events). ${ }^{10-12} \mathrm{We}$ also did subgroup analyses by type of shift work, overall quality of study (top third of Downs and Black score), adjustment for socioeconomic status, and study design (prospective and retrospective cohort versus case-control), again for coronary events (which represented the most commonly reported outcome) as the outcome variable. In addition, we repeated the primary analysis with Duval and Tweedie's trim and fill analysis (to adjust for potential publication bias). ${ }^{13}$ Finally, we calculated the population attributable risk for shift work in terms of the three co-primary outcomes by using data on the prevalence of shift work from the General Social Survey (2010), done by Statistics Canada. ${ }^{14}$ We used Comprehensive Meta-analysis version 2.0 (Englewood, NJ).

\section{Results Study selection}

After removing duplicates, we identified 12350 unique references for screening of titles, abstracts, and keywords (web extra figure A). Of these, we retrieved 146 articles in full and rated 35 as eligible for the review (representing 34 distinct datasets). ${ }^{11}{ }^{1216-48}$ Agreement between reviewers for study inclusion was fair $(\kappa=0.78,95 \%$ confidence interval 0.65 to 0.90).

\section{Study characteristics}

The 34 primary samples comprised 2011935 people (table $1 \Downarrow$ ). Study designs were fairly evenly divided between prospective cohorts $(n=11)$, retrospective cohorts $(n=13)$, and case-control analyses $(n=10)$. Shift schedules were classified as evening shifts ( $n=4$ studies), irregular or unspecified shifts $(n=6)$, mixed schedules $(n=11)$, night shifts $(n=9)$, and rotating shifts $(n=10)$; 
seven studies reported more than one category. Most studies $(n=30)$ used non-shift day workers as the referent category, and the remainder used the general population as controls $(n=4)$. The median Downs and Black score expressed as a proportion was $60 \%$ (interquartile range $34-86 \%$ ); the most common deficiencies were a lack of data on contamination of comparison groups (owing to failure to report exposure over multiple time points) and failure to report all types of adverse vascular events potentially related to shift work (extra figure B).

\section{Primary outcomes}

Ten studies recorded myocardial infarction, 28 recorded any coronary event, and two recorded ischaemic stroke (table $2 \Downarrow$ and extra table C). In pooled random effects analyses, shift work status was associated with an increased risk of myocardial infarction (risk ratio 1.23, 95\% confidence interval 1.15 to 1.31 ; $\left.\mathrm{I}^{2}=0\right)$, coronary events $\left(1.24,1.10\right.$ to $\left.1.39 ; \mathrm{I}^{2}=85 \%\right)$, and ischaemic stroke $\left(1.05,1.01\right.$ to $\left.1.09 ; \mathrm{I}^{2}=0\right)$ (extra figure $\left.\mathrm{C}\right)$. The $\mathrm{I}^{2}$ statistic for coronary events suggested substantial heterogeneity (figure $\downarrow$ ). A side by side comparison of unadjusted and adjusted pooled risk ratios from studies reporting both suggested similar results (table 2).

\section{Secondary outcomes}

No study reported heart failure or haemorrhagic stroke, so we did not consider these endpoints further. Cardiovascular events, coronary mortality, cerebrovascular mortality, cardiovascular mortality, and all cause mortality were reported by five, nine, four, five, and eight studies. All of these outcomes had risk ratios in excess of 1.0, ranging from 1.04 for all cause mortality to 1.24 for cardiovascular events (table $3 \Downarrow$, extra figure D); however, none was statistically significant in random effects models at $\mathrm{P}<0.05$.

\section{Sensitivity analyses}

The Duval and Tweedie trim and fill analysis continued to indicate an increased risk of myocardial infarction and coronary events even after adjustment for publication bias (this analysis was not possible for ischaemic stroke) (table $2 \Downarrow$ ). ${ }^{21}{ }^{27} \mathrm{We}$ regressed the log risk ratio of coronary events against various baseline characteristics, as coronary disease was the only heterogeneous outcome of the three primary events. None of the pre-specified characteristics was statistically significant (extra table D). In pooled subgroup analyses, all types of shift work were associated with an increased risk of coronary events, with the exception of evening shift work; the highest point estimate was noted for night shifts (risk ratio $1.41,1.13$ to 1.76 ) (extra table D). When we isolated studies in the top third of the Downs and Black scores, we continued to observe an increased risk of coronary events (risk ratio 1.18, 1.07 to 1.30 ). We noted similar findings in studies that adjusted for, matched on, or restricted by socioeconomic status (risk ratio 1.19, 1.04 to 1.36). In addition, prospective cohort studies suggested a higher risk of coronary events (risk ratio $1.32,1.07$ to 1.63 ) than did retrospective cohort studies $(1.19,1.06$ to 1.34$)$ or case-control studies $(1.12,1.003$ to 1.25$)$; overall, however, we found no evidence of heterogeneity by study design $(\mathrm{P}=0.39)$. Finally, on the basis of the prevalence of shift workers among the adult working population in Canada (32.8\%), the population attributable risks related to shift work were $7.0 \%$ for myocardial infarction, $7.3 \%$ for coronary events, and $1.6 \%$ for ischaemic stroke, which represent estimates among people employed in the years 2009 and 2010 .

\section{Discussion}

In a comprehensive, up to date review of all available literature, we found that shift work was associated with coronary and cerebrovascular events (table $4 \Downarrow$ ). We found concordance across statistical models, endpoints, shift work schedules, and adjusted versus unadjusted analyses. Neither publication bias nor socioeconomic status seemed to be a problem.

\section{Strengths and weaknesses}

This is the largest synthesis of shift work and vascular risk reported to date. Previous work has been hampered by a narrow focus on only one type of risk (such as coronary disease), a lack of completeness in identifying all relevant studies, absence of quantitative synthesis through conventional meta-analytic techniques, and failure to use a validated tool to assess the quality of studies. We have surmounted these limitations and in addition provide in-depth analyses of methodologically strong studies, the effects of adjusting for socioeconomic status, and comparisons of risk associations against different types of vascular events and different shift work schedules.

On the other hand, several caveats must be noted. As with many meta-analyses of the observational literature, outcome definitions varied somewhat between studies (extra table A); this may have led to heterogeneity in studies' results. Different studies adjusted for different risk factors, although broad consistency between unadjusted and adjusted models was noted. None of the secondary endpoints was statistically significant in relation to shift work, and $95 \%$ confidence intervals were wide. The large number of distinct cardiovascular maladies represented under the rubric "cardiovascular events" in various iterations of the international classification of diseases coding system could have caused imprecision in risk for this entity. In addition, ischaemic stroke was reported by only two studies and cerebrovascular mortality by an additional four studies; pooled together, this gives 4592 events (still substantially less than the numbers of coronary events and deaths). In addition, we were unable to discern any major sources for the heterogeneity seen in the outcome of coronary events. Finally, our dataset lacked discrete information on the diurnal type of workers

("morningness" or "eveningness"), so we could not determine whether associations differed across this important characteristic.

\section{Relation to other studies}

Notwithstanding these limitations, we have identified an epidemiological association between shift work and vascular events. Unfortunately, observational studies such as those synthesised here cannot definitively prove causality. ${ }^{49} 50$ However, other studies have noted that shift workers have higher rates of dyslipidaemia, metabolic syndrome, hypertension, and diabetes. ${ }^{51-53}$ Even a single overnight shift is enough to increase blood pressure and impair variability of heart rate. ${ }^{54}$

Shift work is disruptive to circadian rhythm, impairs sleep quality, and affects work-life balance. ${ }^{55}$ Insomnia, a complaint common among night shift workers, is an independent risk factor for myocardial infarction. ${ }^{35} \mathrm{We}$ found that night shifts were associated with the steepest increase in risk for coronary events (risk ratio $1.41,95 \%$ confidence interval 1.13 to 1.76 ). Shift workers are also more likely to smoke and often have worse socioeconomic status than do day workers, although presence or absence of adjustment for these factors was not a source of heterogeneity in our analyses; accordingly, subgroup analyses limited to studies that accounted for social class still indicated an increase in coronary risk. ${ }^{56}$ Certainly, to the extent that shift work selects for people with worse lifestyle related 
habits, it could be a marker rather than a cause of vascular disease. Yet an increased risk of vascular events was evident even in studies that adjusted for unhealthy behaviours in shift workers. ${ }^{24} 26303545$ Unhealthy behaviour alone thus cannot fully account for the association between shift work and cardiovascular events.

Some data suggest that shift work is associated with neoplasia. Hansen and Lassen recently reported an increased risk of breast cancer among female military employees working night shifts; they observed a clear dose-response relation according to the number of years of night shift work $(\mathrm{P}=0.03)$ and the cumulative number of such shifts $(\mathrm{P}=0.02) .{ }^{58}$ People in the highest third of exposure had a more than twofold increase in the odds of breast cancer (multivariable adjusted odds ratio 2.3, 1.2 to 4.6). Intriguingly, women with morning chronotype preference and exposure to night work greater than the median had even higher risks (adjusted odds ratio 3.9, 1.6 to 9.5). This last finding may suggest a role for disruption of circadian rhythm in the pathogenesis of shift work associated breast cancer.

\section{Study implications}

Our findings have several implications. The increased risk of vascular disease apparent in shift workers, regardless of its explanation, suggests that people who do shift work should be vigilant about risk factor modification. Screening programmes for modifiable risk factors in shift workers have yielded substantial burdens of treatable risk factors, including dyslipidaemia, smoking, glucose intolerance, and hypertension. ${ }^{59-63}$ Shift workers should be educated about cardiovascular symptoms in an effort to forestall or avert the earliest clinical manifestations of disease. Evidence also exists in the literature to suggest that modification and rationalisation of shift schedules may yield dividends in terms of healthier, more productive workers; however, the long term effects of these alterations on vascular outcomes remain unknown. ${ }^{64-66}$ More work is needed to identify the most vulnerable subsets of shift workers and the effects of shift modifying strategies on overall vascular health.

Contributors: MVV, JC, and DGH were involved in conception and design of the study. MVV, DGH, IJ, LEL, AVI, JC, and MM were responsible for data acquisition. MVV, DGH, AXG, GP, and AD analysed and interpreted the data. MVV and DGH drafted the manuscript, which was critically revised for important intellectual content by all authors. MVV, DGH, and AD did the statistical analysis. DGH obtained funding. $\mathrm{JC}$ and $\mathrm{AVI}$ provided administrative, technical, or material support. DGH supervised the study and is the guarantor.

Funding: MVV was supported by a Canadian Institutes for Health Research (CIHR) strategic training program fellowship in vascular disease. AXG was supported by a CIHR clinician scientist award. DGH and GP were supported by CIHR new investigator awards.

Competing interests: All authors have completed the Unified Competing Interest form at www.icmje.org/coi_disclosure.pdf (available on request from the corresponding author) and declare: no support from any organisation for the submitted work; no financial relationships with any organisations that might have an interest in the submitted work in the previous three years; no other relationships or activities that could appear to have influenced the submitted work.

Ethical approval: Not needed.

Data sharing: Technical appendix, statistical code, and dataset are available from the corresponding author (dhackam@uwo.ca).

Williams C. Work-life balance of shift workers. Volume 9, issue 8. Statistics Canada, 2008. 2 Hale HB, Williams EW, Smith BN, Melton CE Jr. Neuroendocrine and metabolic responses to intermittent night shift work. Aerosp Med 1971;42:156-62.
3 Wang XS, Armstrong MEG, Cairns BJ, Key TJ, Travis RC. Shift work and chronic disease: the epidemiological evidence. Occup Med 2011:61:78-89.

4 Boggild $\mathrm{H}, \mathrm{Knutsson} A$. Shift work, risk factors and cardiovascular disease. Scand J Work Environ Health 1999;25:85-99.

5 Frost P, Kolstad HA, Bonde JP. Shift work and the risk of ischemic heart disease-a systematic review of the epidemiologic evidence. Scand J Work Environ Health 2009;35:163-79.

6 Moher D, Liberati A, Tetzlaff J, Altman DG, the PRISMA Group. Preferred reporting items for systematic reviews and meta-analyses: the PRISMA statement. Ann Intern Med 2009;151:264-9.

7 Downs $\mathrm{SH}, \mathrm{Black} \mathrm{N}$. The feasibility of creating a checklist for the assessment of the methodological quality both of randomised and non-randomised studies of health care interventions. J Epidemiol Community Health 1998;52:377-84.

8 Higgins JP, Thompson SG. Quantifying heterogeneity in a meta-analysis. Stat Med 2002;21:1539-58.

9 Balshem $\mathrm{H}$, Helfand M, Schunemann HJ, Oxman AD, Kunz R, Brozek J, et al. GRADE guidelines: 3. Rating the quality of evidence. J Clin Epidemiol 2011;64:4016.

10 Nabe-Nielsen K, Garde AH, Tuchsen F, Hogh A, Diderichsen F. Cardiovascular risk factors and primary selection into shift work. Scand J Work Environ Health 2008;34:206-12.

11 Boggild $\mathrm{H}$, Suadicani P, Hein HO, Gyntelberg F. Shift work, social class, and ischaemic heart disease in middle aged and elderly men; a 22 year follow up in the Copenhagen Male Study. Occup Environl Med 1999;56:640-5.

12 Yadegarfar G, McNamee R. Shift work, confounding and death from ischaemic heart disease. Occup Environ Med 2008;65:158-63.

13 Duval S, Tweedie R. Trim and fill: a simple funnel-plot-based method of testing and adjusting for publication bias in meta-analysis. Biometrics 2000;56:455-63.

14 General Social Survey. Cycle 24: time stress and well-being. Statistics Canada, 2010.

15 Chang MH, Hahn RA, Teutsch SM, Hutwagner LC. Multiple risk factors and population attributable risk for ischemic heart disease mortality in the United States, 1971-1992. J Clin Epidemiol 2001;54:634-44.

16 Akerstedt T, Kecklund G, Johansson SE. Shift work and mortality. Chronobiol Int 2004:21:1055-61.

17 Alfredsson L, Spetz CL, Theorell T. Type of occupation and near-future hospitalization for myocardial infarction and some other diagnoses. Int J Epidemiol 1985;14:378-88.

18 Allesoe K, Hundrup YA, Thomsen JF, Osler M. Psychosocial work environment and risk of ischaemic heart disease in women: the Danish Nurse Cohort Study. Occup Environ Med 2010;67:318-22.

19 Babisch W, Beule B, Schust M, Kersten N, Ising H. Traffic noise and risk of myocardial infarction. Epidemiology 2005;16:33-40

20 Biggi N, Consonni D, Galluzzo V, Sogliani M, Costa G. Metabolic syndrome in permanent night workers. Chronobiol Int 2008;25:443-54.

21 Brown DL, Feskanich D, Sánchez BN, Rexrode KM, Schernhammer ES, Lisabeth LD. Rotating night shift work and the risk of ischemic stroke. Am J Epidemiol 2009;169:1370-7.

22 Ellingsen T, Bener A, Gehani AA. Study of shift work and risk of coronary events. J R Soc Promot Health 2007;127:265-7.

23 Falger PR, Schouten EG. Exhaustion, psychological stressors in the work environment, and acute myocardial infarction in adult men. J Psychosom Res 1992;36:777-86.

24 Fujino $\mathrm{Y}$, Iso H, Tamakoshi A, Inaba $\mathrm{Y}$, Koizumi A, Kubo T, et al. A prospective cohort study of shift work and risk of ischemic heart disease in Japanese male workers. Am J Epidemiol 2006;164:128-35.

25 Fukuoka Y, Dracup K, Froelicher ES, Ohno M, Hirayama H, Shiina H, et al. Do Japanese workers who experience an acute myocardial infarction believe their prolonged working hours are a cause? Int J Cardiol 2005;100:29-35.

26 Haupt CM, Alte D, Dörr M, Robinson DM, Felix SB, John U, et al. The relation of exposure to shift work with atherosclerosis and myocardial infarction in a general population. Atherosclerosis 2008;201:205-11.

27 Hermansson J, Gillander G, Karlsson B, Lindahl B, Stegmayr B, Knutsson A. Ischemic stroke and shift work. Scand J Work Environ Health 2007;33:435-9.

28 Hublin C, Partinen M, Koskenvuo K, Silventoinen K, Koskenvuo M, Kaprio J. Shift-work and cardiovascular disease: a population-based 22-year follow-up study. Eur J Epidemiol 2010;25:315-23.

29 Karlsson B, Alfredsson L, Knutsson A, Andersson E, Torén, K. Total mortality and cause-specific mortality of Swedish shift- and dayworkers in the pulp and paper industry in 1952-2001. Scand J Work Environ Health 2005;31:30-5.

30 Kawachi I, Colditz GA, Stampfer MJ, Willett WC, Manson JE, Speizer FE, et al. Prospective study of shift work and risk of coronary heart disease in women. Circulation 1995;92:3178-82.

31 Knutsson A, Akerstedt T, Jonsson BG, Orth-Gomer K. Increased risk of ischaemic heart disease in shift workers. Lancet 1986;2:89-92.

32 Knutsson A, Hallquist J, Reuterwall C, Theorell T, Akerstedt T. Shiftwork and myocardial infarction: a case-control study. Occup Environ Med 1999;56:46-50.

33 Knutsson A, Hammar N, Karlsson B. Shift workers' mortality scrutinized. Chronobiol Int 2004;21:1049-53.

34 Koller M. Health risks related to shift work: an example of time-contingent effects of long-term stress. Int Arch Occup Environ Health 1983:53:59-75.

35 Laugsand LE, Vatten LJ, Platou C, Janszky I. Insomnia and the risk of acute myocardial infarction. Circulation 2011;124:2073-81.

36 Liu Y, Tanaka H, Fukuoka Heart Study Group. Overtime work, insufficient sleep, and risk of non-fatal acute myocardial infarction in Japanese men. Occup Environ Med 2002;59:447-51.

37 McNamee R, Binks K, Jones S, Faulkner D, Slovak A, Cherry NM. Shiftwork and mortality from ischaemic heart disease. Occup Environ Med 1996:53:367-73.

38 Netterstrom B, Nielsen FE, Kristensen TS, Bach E, Moller L. Relation between job strain and myocardial infarction: a case-control study. Occup Environ Med 1999;56:339-42.

39 Rafnsson V, Gunnarsdóttir H. Mortality study of fertiliser manufacturers in Iceland. Br J Industrial Med 1990;47:721-5.

40 Steenland K, Fine L. Shift work, shift change, and risk of death from heart disease at work. Am J Industrial Med 1996;29:278-81.

41 Tarumi K. Mortality and work conditions: a retrospective follow-up assessment of the effects of work conditions on the mortality of male employees in the manufacturing industry. J UOEH 1997;19:193-205.

42 Taylor PJ, Pocock SJ, Sergean R. Absenteeism of shift and day workers: a study of six types of shift system in 29 organizations. Br J Industrial Med 1972;29:208-13.

43 Taylor PJ, Pocock SJ. Mortality of shift and day workers 1956-68. Br J Industrial Med 1972;29:201-7. 


\section{What is already known on this topic}

Shift work is associated with an increased risk of hypertension, metabolic syndrome, dyslipidaemia, and diabetes mellitus

Disruption of circadian rhythm may predispose shift workers to vascular events; however, no organised systematic synthesis of all types

of vascular events is available

\section{What this study adds}

Shift work is associated with myocardial infarction, coronary events, and ischaemic stroke; the relative risks are modest, but population attributable risks are high

These findings seem to be robust and insensitive to publication bias, quality of study, and socioeconomic status Conversely, shift work is not associated with increased rates of mortality (whether vascular cause specific or overall)

44 Tuchsen F. Working hours and ischaemic heart disease in Danish men: a 4-year cohort study of hospitalization. Int J Epidemiol 1993;22:215-21.

45 Tuchsen F, Hannerz H, Burr H. A 12 year prospective study of circulatory disease among Danish shift workers. Occup Environ Med 2006;63:451-5.

46 Vertin PG. Incidence of cardiovascular diseases in the Dutch viscose rayon industry. J Occup Med 1978;20:346-50.

47 Virkkunen H, Härmä M, Kauppinen T, Tenkanen L. The triad of shift work, occupational noise, and physical workload and risk of coronary heart disease. Occup Environ Med 2006;63:378-86.

48 Virtanen SV, Notkola V. Socioeconomic inequalities in cardiovascular mortality and the role of work: a register study of Finnish men. Int J Epidemiol 2002;31:614-21.

49 Puttonen S, Harma M, Hublin C. Shift work and cardiovascular disease-pathways from circadian stress to morbidity. Scand J Work Environ Health 2010;36:96-108.

50 Szosland D. Shift work and metabolic syndrome, diabetes mellitus and ischaemic heart disease. Int J Occup Med Environ Health 2010;23:287-91.

51 Pan A, Schernhammer ES, Sun Q, Hu FB. Rotating night shift work and risk of type 2 diabetes: two prospective cohort studies in women. PLoS Med 2011;8:e1001141.

52 Lieu SJ, Curhan GC, Schernhammer ES, Forman JP. Rotating night shift work and disparate hypertension risk in African-Americans. J Hypertens 2012;30:61-6.

53 Uetani M, Sakata K, Oishi M, Tanaka K, Nakada S, Nogawa K, et al. The influence of being overweight on the relationship between shift work and increased total cholesterol level. Ann Epidemiol 2011;21:327-35

54 Lo SH, Lin LY, Hwang JS, Chang YY, Liau CS, Wang JD. Working the night shift causes increased vascular stress and delayed recovery in young women. Chronobiol Int 2010;27:1454-68.

55 Garde AH, Hansen AM, Hansen J. Sleep length and quality, sleepiness and urinary melatonin among healthy Danish nurses with shift work during work and leisure time. Int Arch Occup Environ Health 2009;82:1219-28.

56 Knutsson A, Nilsson T. Tobacco use and exposure to environmental tobacco smoke in relation to certain work characteristics. Scand J Soc Med 1998;26:183-9.

57 Moller L, Kristensen TS, Hollnagel H. Social class and cardiovascular risk factors in Danish men. Scand J Soc Med 1991:19:116-26.

58 Hansen J, Lassen CF. Nested case control study of night shift work and breast cancer risk among women in the Danish military. Occup Environl Med 2012; published online 29 May.
59 Lin YC, Hsiao TJ, Chen PC. Shift work aggravates metabolic syndrome development among early-middle-aged males with elevated ALT. World J Gastroenterol 2009;15:5654-61.

60 Suwazono Y, Dochi M, Sakata K, Okubo Y, Oishi M, Tanaka K, et al. A longitudinal study on the effect of shift work on weight gain in male Japanese workers. Obesity (Silver Spring) 2008;16:1887-93.

61 Copertaro A, Bracci M, Barbaresi M, Santarelli L Assessment of cardiovascular risk in shift healthcare workers. Eur J Cardiovasc Prev Rehabil 2008;15:224-9.

62 Peter R, Alfredsson L, Knutsson A, Siegrist J, Westerholm P. Does a stressful psychosocial work environment mediate the effects of shift work on cardiovascular risk factors? Scand $J$ Work Environ Health 1999;25:376-81.

63 Ruidavets JB, Cambou JP, Esquirol Y, Soulat JM, Ferrieres J. [Cardiovascular risk factors and shift work in men living in Haute-Garonne, France.] Arch Mal Coeur Vaiss 1998;91:957-62.

64 Karlson B, Eek F, Orbaek P, Osterberg K. Effects on sleep-related problems and self-reported health after a change of shift schedule. J Occup Health Psychol 2009;14:97-109.

65 Cappuccio FP, Bakewell A, Taggart FM, Ward G, Ji C, Sullivan JP, et al. Implementing a $48 \mathrm{~h}$ EWTD-compliant rota for junior doctors in the UK does not compromise patients' safety: assessor-blind pilot comparison. QJM 2009:102:271-82.

66 Vittasalo K, Kuosma E, Laitinen J, Harma M. Effects of shift rotation and the flexibility of a shift system on daytime alertness and cardiovascular risk factors. Scand J Work Environ Health 2008;34:198-205.

\section{Accepted: 21 June 2012}

\section{Cite this as: BMJ 2012:345:e4800}

This is an open-access article distributed under the terms of the Creative Commons Attribution Non-commercial License, which permits use, distribution, and reproduction in any medium, provided the original work is properly cited, the use is non commercial and is otherwise in compliance with the license. See: http://creativecommons.org/licenses/bync/2.0/ and http://creativecommons.org/licenses/by-nc/2.0/legalcode. 


\section{Tables}

\section{Table 1| Characteristics of studies}

\begin{tabular}{|c|c|c|c|c|}
\hline Study & Design* & Setting/data source & Sample & Outcomes \\
\hline Akerstedt et al, 2004 & Retrospective cohort & $\begin{array}{l}\text { Swedish Living Conditions } \\
\text { Survey }\end{array}$ & 22411 & All cause mortality \\
\hline Alfredsson et al, 1985 & Retrospective cohort & Swedish census data & 958096 & Myocardial infarction \\
\hline Allesoe et al, 2011 & Prospective cohort & Danish Nurse Cohort Study & 12116 & Coronary events \\
\hline Babisch et al, 2005 & Case-control & $\begin{array}{l}32 \text { major hospitals in Berlin, } \\
\text { Germany }\end{array}$ & 4115 & Myocardial infarction \\
\hline
\end{tabular}

Age, stress, physically strenuous work, smoking, chronic disease

Age, county

Age, family history, diabetes, menopause, $\mathrm{BMI}$, smoking, alcohol consumption, leisure time activity, physical activity at work

Age, diabetes, hypertension, family history, smoking, BMI, employment status, living without a partner, noise sensitivity, education, sext, hospital†

\begin{tabular}{lllll}
\hline Biggi et al, 2008 & Retrospective cohort & $\begin{array}{l}\text { Municipal workers in Milan, } \\
\text { Italy }\end{array}$ & 468 & Coronary events \\
\hline Boggild et al, 1999 & Prospective cohort & Copenhagen Male Study & 5207 & $\begin{array}{l}\text { Coronary events, all cause } \\
\text { mortality }\end{array}$ \\
\hline Brown et al, 2009 & Prospective cohort & Nurses' Health Study & 80108 & Ischaemic stroke
\end{tabular}

No covariate adjustment

Age, social class, sleep, tobacco, weight, height, fitness

Age, questionnaire cycle, physical activity, $\mathrm{BMI}$, alcohol, fruit and vegetable intake, menopausal status, smoking, hormone replacement, aspirin use, diabetes, coronary disease, blood pressure, serum cholesterol, husband's education, snoring, sleep duration, atrial fibrillation

\begin{tabular}{|c|c|c|c|c|c|}
\hline Ellingsen et al, 2007 & Retrospective cohort & $\begin{array}{l}\text { Employees of fertilizer plant } \\
\text { in Doha, Qatar }\end{array}$ & 2562 & $\begin{array}{l}\text { Coronary and } \\
\text { cardiovascular events }\end{array}$ & No covariate adjustment \\
\hline $\begin{array}{l}\text { Falger and Schouten, } \\
1992\end{array}$ & Case-control & $\begin{array}{l}\text { Two large hospitals in } \\
\text { Netherlands }\end{array}$ & 458 & Myocardial infarction & $\begin{array}{l}\text { Age, exhaustion, smoking, education, hospital } \\
\text { site } \dagger\end{array}$ \\
\hline Fujino et al, 2006 & Prospective cohort & Survey data in Japan & 17649 & $\begin{array}{l}\text { Coronary, cardiovascular, } \\
\text { cerebrovascular, and all } \\
\text { cause mortality }\end{array}$ & $\begin{array}{l}\text { Age, smoking, alcohol, education, perceived } \\
\text { stress, past medical history, BMI, hours of } \\
\text { walking, hours of exercise, job type }\end{array}$ \\
\hline Fukuoka et al, 2005 & Case-control & Five hospitals in Japan & 94 & Myocardial infarction & Age $\dagger$, work status $\uparrow$, sex $\dagger$ \\
\hline Haupt et al, 2008 & Retrospective cohort & $\begin{array}{l}\text { Survey data in West } \\
\text { Pomerania, Germany }\end{array}$ & 2510 & Myocardial infarction & $\begin{array}{l}\text { Age, sex, food frequency score, } \\
\text { socioeconomic status, smoking }\end{array}$ \\
\hline $\begin{array}{l}\text { Hermansson et al, } \\
2007\end{array}$ & Case-control & Survey data in Sweden & 607 & Ischaemic stroke & $\begin{array}{l}\text { Age, smoking, education, job strain, } \mathrm{BP}, \\
\text { serum triglycerides, cholesterol, sex } \uparrow, \\
\text { survey†, survey date†, locale }\end{array}$ \\
\hline Hublin et al, 2010 & Prospective cohort & $\begin{array}{l}\text { Population based twin } \\
\text { cohort in Finland }\end{array}$ & 20142 & $\begin{array}{l}\text { Coronary mortality, } \\
\text { cardiovascular events }\end{array}$ & $\begin{array}{l}\text { Age, marital status, social class, education, } \\
\text { smoking, binge drinking, alcohol, } \\
\text { hypertension, BMI, conditioning physical } \\
\text { activity, life satisfaction, diurnal type, sleep } \\
\text { length, use of hypnotics or tranquillisers, } \\
\text { physical workload, working pace }\end{array}$ \\
\hline Karlsson et al, 2005 & Retrospective cohort & $\begin{array}{l}\text { Pulp and paper workers in } \\
\text { Sweden }\end{array}$ & 5442 & $\begin{array}{l}\text { Coronary, stroke related, } \\
\text { and all cause mortality }\end{array}$ & Age, duration of employment \\
\hline Kawachi et al, 1995 & Prospective cohort & Nurses' Health Study & 79109 & $\begin{array}{l}\text { Myocardial infarction, } \\
\text { coronary events, coronary } \\
\text { and all cause mortality, } \\
\text { cardiovascular events }\end{array}$ & $\begin{array}{l}\text { Age, smoking, diabetes, hypertension, } \\
\text { hypercholesterolaemia, past oral contraceptive } \\
\text { use, current use of hormonal replacement, } \\
\text { parental MI before age } 60 \text {, alcohol, physical } \\
\text { activity, BMI, aspirin use, fifths of vitamin E, } \\
\text { follow-up period, husband's education }\end{array}$ \\
\hline Knutsson et al, 1986 & Prospective cohort & $\begin{array}{l}\text { Pulp and paper works in } \\
\text { Sweden }\end{array}$ & 504 & Coronary events & $\begin{array}{l}\text { Age, duration of exposure, smoking, family } \\
\text { status }\end{array}$ \\
\hline Knutsson et al, 1999 & Case-control & Survey data in Sweden & 4648 & Myocardial infarction & $\begin{array}{l}\text { Age†, sex } \dagger \text {, residence } \dagger \text {, smoking, job strain, } \\
\text { education }\end{array}$ \\
\hline Koller, 1983 & Retrospective cohort & $\begin{array}{l}\text { Oil refinery workers in } \\
\text { Austria }\end{array}$ & 301 & $\begin{array}{l}\text { Coronary and } \\
\text { cardiovascular events }\end{array}$ & Age $\dagger$, duration of employment $\dagger$ \\
\hline Laugsand et al, 2011 & Prospective cohort & $\begin{array}{l}\text { Nord-Trøndelag Health } \\
\text { Study (survey in Norway) }\end{array}$ & 52610 & Myocardial infarction & $\begin{array}{l}\text { Age, sex, marital status, education, shift work, } \\
\text { systolic blood pressure, total cholesterol, } \\
\text { diabetes mellitus, BMI, physical activity, } \\
\text { smoking, depression, poor sleep }\end{array}$ \\
\hline
\end{tabular}


Table 1 (continued)

\begin{tabular}{|c|c|c|c|c|c|}
\hline Study & Design* & Setting/data source & Sample & Outcomes & Variables accounted for \\
\hline Liu and Tanaka, 2002 & Case-control & 22 hospitals in Japan & 705 & Myocardial infarction & Age†, sex†, residence† \\
\hline McNamee et al, 1996 & Case-control & Nuclear plant workers & 934 & Coronary mortality & $\begin{array}{l}\text { Aget, smoking, BMI, height, systolic BP, } \\
\text { diastolic BP, job status, duration of } \\
\text { employment, year of starting work } \dagger\end{array}$ \\
\hline Netterstrom et al, 1999 & Case-control & Two Danish hospitals & 252 & Myocardial infarction & Aget, sex† \\
\hline $\begin{array}{l}\text { Rafnsson and } \\
\text { Gunnarsdottir, } 1990\end{array}$ & Retrospective cohort & $\begin{array}{l}\text { Fertiliser plant workers in } \\
\text { Iceland }\end{array}$ & 603 & $\begin{array}{l}\text { Coronary and all cause } \\
\text { mortality }\end{array}$ & Age, calendar year \\
\hline $\begin{array}{l}\text { Steenland and Fine, } \\
1996\end{array}$ & Case-control & $\begin{array}{l}\text { Heavy equipment plant } \\
\text { workers (US) }\end{array}$ & 944 & Coronary mortality & Age, worksite, race \\
\hline Tarumi, 1997 & Retrospective cohort & $\begin{array}{l}\text { Japanese steel industry } \\
\text { workers }\end{array}$ & 9141 & $\begin{array}{l}\text { Cardiovascular and all } \\
\text { cause mortality }\end{array}$ & Age, job site location, blue collar status $†$ \\
\hline $\begin{array}{l}\text { Taylor and Pocock } \\
\text { (reanalysed by } \\
\text { Knutsson et al, 2004) }\end{array}$ & Retrospective cohort & $\begin{array}{l}10 \text { industrial organisations } \\
\text { in Britain }\end{array}$ & 8767 & $\begin{array}{l}\text { Coronary and } \\
\text { cerebrovascular mortality, } \\
\text { cardiovascular and total } \\
\text { mortality }\end{array}$ & Age, calendar period, sex $\dagger$ \\
\hline Taylor et al, 1972 & Retrospective cohort & $\begin{array}{l}29 \text { industrial organisations } \\
\text { in Britain }\end{array}$ & 1930 & Cardiovascular events & Age $\dagger$, organisation $\dagger$, occupation $\dagger$ \\
\hline Tuchsen, 1993 & Prospective cohort & Danish survey data & 406969 & Coronary events & Age, sex $\uparrow$ \\
\hline Tuchsen et al, 2006 & Prospective cohort & Danish survey data & 5517 & $\begin{array}{l}\text { Coronary and } \\
\text { cardiovascular events }\end{array}$ & $\begin{array}{l}\text { Annoying noise, coldness, conflicts at work, } \\
\text { high cognitive demands, ergonomic exposure, } \\
\text { job insecurity, passive smoking, monotonous } \\
\text { tasks, low decision authority, heat, walking or } \\
\text { standing for long hours at work, low social } \\
\text { support, BMI, current smoking }\end{array}$ \\
\hline Vertin, 1978 & Prospective cohort & $\begin{array}{l}\text { Viscose rayon factory } \\
\text { workers }\end{array}$ & 200 & Coronary events & Carbon disulfide exposure $†$ \\
\hline Virkunnen et al, 2006 & Prospective cohort & $\begin{array}{l}\text { Helsinki Heart Study } \\
\text { (clinical trial) }\end{array}$ & 1804 & Coronary events & $\begin{array}{l}\text { Age, smoking, systolic BP, cholesterol, BMI, } \\
\text { gemfibrozil use, noise, physical workload }\end{array}$ \\
\hline $\begin{array}{l}\text { Virtanen and Notkola, } \\
2002\end{array}$ & Retrospective cohort & Finnish census data & 385500 & $\begin{array}{l}\text { Cerebrovascular and } \\
\text { cardiovascular mortality }\end{array}$ & $\begin{array}{l}\text { Age, marital status, professional status, } \\
\text { education, income, socioeconomic status, job } \\
\text { exposure variables }\end{array}$ \\
\hline $\begin{array}{l}\text { Yadegarfar and } \\
\text { McNamee, } 2008\end{array}$ & Case-control & $\begin{array}{l}\text { Nuclear plant workers in } \\
\text { Britain }\end{array}$ & 1270 & Coronary mortality & $\begin{array}{l}\text { Aget, year of starting workt, smoking, systolic } \\
\mathrm{BP} \text {, diastolic BP, BMI, height, work status, } \\
\text { duration employment, social class }\end{array}$ \\
\hline
\end{tabular}

$\mathrm{BMI}=$ body mass index; $\mathrm{BP}=$ blood pressure.

*All studies used day workers as comparison group, with four exceptions that used general population controls-Alfredsson et al, Rafnsson et al, Taylor et al, and Tuchsen 1993.

†Matching or stratifying variable. 
Table 2| Primary outcomes

\begin{tabular}{lccc}
$\begin{array}{l}\text { Analysis } \\
\text { Random effects }\end{array}$ & Events (studies) & Risk ratio (95\% Cl) & $\mathbf{I}^{\mathbf{2}}$ \\
\hline Myocardial infarction & $6598(10) \dagger$ & $1.23(1.15$ to 1.31$)$ & $0 \%$ \\
\hline All coronary events & $17359(28) \dagger$ & $1.24(1.10$ to 1.39$)$ & $85 \%$ \\
\hline Ischaemic stroke & $1854(2) \dagger$ & $1.05(1.01$ to 1.09$)$ & $0 \%$ \\
\hline Sensitivity analyses $¥$ & & & $70 \%$ \\
\hline Myocardial infarction, unadjusted & $4408(5)$ & $1.41(1.17$ to 1.70$)$ & $35 \%$ \\
\hline Myocardial infarction, adjusted & $4408(5)$ & $1.27(1.10$ to 1.45$)$ & $76 \%$ \\
\hline Coronary events, unadjusted & $8154(12)$ & $1.21(1.06$ to 1.39$)$ & $56 \%$ \\
\hline Coronary events, adjusted & $8154(12)$ & $1.17(1.05$ to 1.31$)$ & $0 \%$ \\
\hline Ischaemic stroke, unadjusted & $1854(2)$ & $1.09(1.04$ to 1.14$)$ & $0 \%$ \\
\hline Ischaemic stroke, adjusted & $1854(2)$ & $1.05(1.01$ to 1.09$)$ & \\
\hline Trim and filled estimates & & $1.22(1.15$ to 1.30$)$ & NA \\
\hline Myocardial infarction & $(12) \S$ & $1.19(1.06$ to 1.34$)$ & NA \\
\hline All coronary events & $(32) \S$ & - & - \\
\hline Ischaemic strokeף & - & - & \\
\hline
\end{tabular}

$\mathrm{NA}=$ not applicable.

*These analyses preferentially pooled adjusted risk estimates, with unadjusted estimates included only for studies that reported crude estimates alone. †Random effects mean event risks for myocardial infarction, coronary events, and ischaemic stroke were $0.8 \%, 2.9 \%$, and $2.1 \%$ (totalled over follow-up for cohort studies).

$\ddagger$ These analyses pooled subset of studies that reported both unadjusted and adjusted risk estimates.

§Includes hypothetical unpublished studies imputed to left of mean.

IDuvall and Tweedie's trim and fill method could not be applied, as only two studies were reported. 


\section{Table 3| Secondary outcomes}

\begin{tabular}{lccccc}
\hline Outcome* & Events (studies) & Event riskt & Random effects risk ratio (95\% Cl) & Fixed effects risk ratio (95\% Cl) & $\mathbf{I}^{2}$ \\
Cardiovascular events & $1423(5)$ & $6.4 \%$ & $1.24(0.81$ to 1.89$)$ & $1.30(1.13$ to 1.50$)$ & $85 \%$ \\
\hline Coronary mortality & $3166(9)$ & $1.8 \%$ & $1.08(0.97$ to 1.21$)$ & $1.07(0.99$ to 1.17$)$ & $29 \%$ \\
\hline Cerebrovascular mortality & $2738(4)$ & $1.0 \%$ & $1.12(0.89$ to 1.40$)$ & $1.12(0.99$ to 1.28$)$ & $52 \%$ \\
\hline Cardiovascular mortality & $17335(5)$ & $1.2 \%$ & $1.14(0.98$ to 1.32$)$ & $1.04(0.99$ to 1.09$)$ & $65 \%$ \\
\hline All cause mortality & $8092(8)$ & $8.0 \%$ & $1.04(0.97$ to 1.11$)$ & $1.03(0.98$ to 1.09$)$ & $36 \%$ \\
\hline
\end{tabular}

*See web extra table A for study level definitions.

†Random effects mean event risk totalled over follow-up for cohort studies. 
Table 4 | Summary of findings: is shift work associated with an increased risk of cardiovascular events?*

\begin{tabular}{|c|c|c|c|c|c|c|c|c|}
\hline Outcomes & Risk of bias & Inconsistency & Indirectness & Imprecision & $\begin{array}{l}\text { Publication } \\
\text { bias }\end{array}$ & $\begin{array}{c}\text { No of } \\
\text { participants } \\
\text { (studies) }\end{array}$ & $\begin{array}{l}\text { Relative effect } \\
\qquad(95 \% \mathrm{Cl})\end{array}$ & $\begin{array}{c}\text { Quality of } \\
\text { evidence (GRADE) }\end{array}$ \\
\hline $\begin{array}{l}\text { Myocardial } \\
\text { infarction }\end{array}$ & Not likely† & $\begin{array}{l}\text { No serious } \\
\text { inconsistency } \neq\end{array}$ & $\begin{array}{l}\text { No serious } \\
\text { indirectness§ }\end{array}$ & $\begin{array}{l}\text { No serious } \\
\text { imprecision }\end{array}$ & Not likely** & $1082977(10)$ & $\begin{array}{c}1.23(1.15 \text { to } \\
1.31)\end{array}$ & Moderate $\dagger \uparrow \oplus \oplus \oplus \mathrm{O}$ \\
\hline Coronary events & Not likely† & Inconsistencył‡ & $\begin{array}{l}\text { No serious } \\
\text { indirectness§ }\end{array}$ & $\begin{array}{l}\text { No serious } \\
\text { imprecision } \rrbracket\end{array}$ & Not likely** & $1530070(28)$ & $\begin{array}{c}1.24(1.10 \text { to } \\
1.39)\end{array}$ & Low $\dagger \dagger \oplus \oplus$ OO \\
\hline $\begin{array}{l}\text { Ischaemic } \\
\text { stroke }\end{array}$ & Not likely† & $\begin{array}{l}\text { No serious } \\
\text { inconsistency } \ddagger\end{array}$ & $\begin{array}{l}\text { No serious } \\
\text { indirectness } \S\end{array}$ & $\begin{array}{l}\text { No serious } \\
\text { imprecision }\end{array}$ & Undetected§§ & $80787(2)$ & $\begin{array}{c}1.05 \text { (1.01 to } \\
1.09)\end{array}$ & Moderate $\dagger \dagger \oplus \oplus \oplus \mathrm{O}$ \\
\hline
\end{tabular}

†Median Downs and Black score for included studies was 60\% (interquartile range $34-86 \%$ ).

$\ddagger 1^{2}=0 \%$.

§Population, outcome, and intervention were consistent with question of interest, although individual studies varied.

ףNo of events and participants studied in review is large, and confidence interval does not include null value.

**Estimates adjusted for publication bias did not differ from observed estimates.

††Dilution effect of single time point exposure ascertainment allows upgrading of evidence.

$\ddagger \ddagger I^{2}=85 \%$.

$\S \S$ Publication bias could not be tested for two studies. 


\section{Figure}

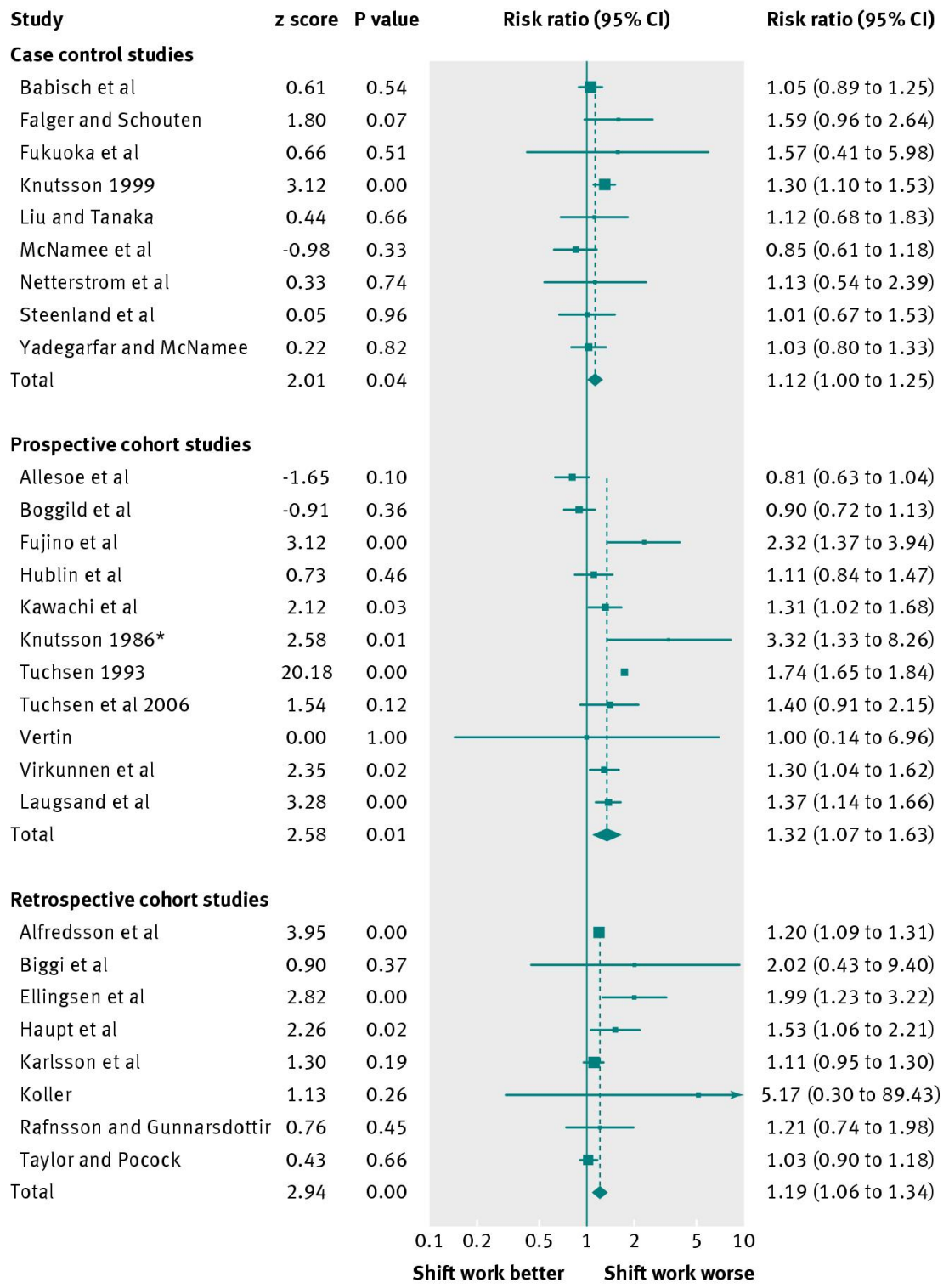

Meta-analysis of coronary events. Studies were combined using a random effects generic inverse variance model after stratification by study design. ${ }^{*}$ Risk ratio and $95 \%$ confidence interval recalculated from original study data over duration of follow-up 